\title{
Development of a Basic Rate of Household Energy Consumption Considering Usage Time and Quantity of Consumer Durables
}

\author{
Takuto Inaba ${ }^{1}$, Tomohiro Tabata ${ }^{* 2}$, Tsai Peii $^{3}$ \\ ${ }^{1}$ Faculty of Human Development, Kobe University, 3-11 Tsurukabuto, Nada-ku, Kobe 657-8501, Japan \\ e-mail: takublack0210@yahoo.co.jp \\ ${ }^{2}$ Graduate School of Human Development and Environment, Kobe University, 3-11 Tsurukabuto, Nada-ku, \\ Kobe 657-8501, Japan \\ e-mail: tabata@people.kobe-u.ac.jp \\ ${ }^{3}$ Graduate School of Human Development and Environment, Kobe University, 3-11 Tsurukabuto, Nada-ku, \\ Kobe 657-8501, Japan \\ e-mail: peii.tsai@people.kobe-u.ac.jp
}

Cite as: Inaba, T., Tabata, T., Peii, T., Development of a Basic Rate of Household Energy Consumption Considering Usage Time and Quantity of Consumer Durables, J. sustain. dev. energy water environ. syst., 5(4), pp 533-545, 2017, DOI: http://dx.doi.org/10.13044/j.sdewes.d5.0159

\begin{abstract}
This study is a survey conducted in questionnaire format on the usage time and the quantity of consumer durables that consume energy, relevant to households in Kobe, Japan. Based on the data containing quantity and daily usage days of consumer durables obtained from the questionnaire survey, the rate of energy consumption for each household type was calculated. By using results, energy consumption of household sector in Kobe in 2010 was estimated at approximately 25,559 TJ. Taking future changes in the number of households in Kobe into consideration, the future energy consumption in 2035 would decline by approximately $6.0 \%$ from 2010. We also revealed that full electrification of residential houses would change energy consumption structures rather than overall the energy consumption.
\end{abstract}

\section{KEYWORDS}

Population decline, Elderly people, Usage time and quantity of consumer durables, Questionnaire survey, Household energy consumption, Projected household energy consumption.

\section{INTRODUCTION}

Approximately $90 \%$ of the greenhouse gases emitted in Japan are associated with the combustion of fossil fuels. However, potentially, the stable supply of fossil fuels could be jeopardised by factors such as a deterioration of the geopolitical circumstances in the source countries of the Middle East. An inadequate and unreliable fossil fuel supply could pose a significant risk to the economic and social activities of Japan. Consequently, in view of the efforts to reduce global warming and increase energy security, earnest consideration has to be given to convert from an energy supply dependent on fossil fuels. Furthermore, the current energy consumption structures need to be reviewed.

\footnotetext{
* Corresponding author
} 
The energy consumption of the residential sector comprises approximately $14.4 \%$ of the total consumption in Japan [1]. Although this value is lower than those of the industrial and transportation sectors, the growth rate of energy consumption of the residential sector has doubled during the fiscal years 1973-2013. Therefore, compared with the industrial and transportation sectors, this value is extremely high [1]. Diverse factors influence the increase in energy consumption of the residential sector in Japan. These factors include a change in lifestyle, requiring convenience and comfort, and changes in social structures, such as an increased number of households coupled with a rise in the number of 1-person household, and others. In recent years, especially, the main factors in the increased household energy consumption have been an increase in the number of households and amount of possession of electric appliances [2].

To counteract the rise in energy consumption by the residential sector, there is a move toward electricity conservation, as well as using alternative sources for energy production, such as solar panels. In addition, various municipalities in Japan are promoting energy saving countermeasures. Several factors need to be considered in investigating the energy consumption and reduction in households, such as the type of domestic building (detached home, housing complex, thermal insulation performance, etc.) and the type of household (number of individuals per household, age of the head of household, etc.). It is often problematic to research the energy consumption of the domestic sector, as household energy consumption patterns differ widely and personal information is not obtained easily [3]. However, various methods are being developed to estimate the consumption of energy, taking into account these difficulties. These methods are classified as top-down and bottom-up approaches [3].

The top-down approach is used to estimate the energy consumption of the overall residential sector. Examples of worldwide studies on this topic include a study relevant to every city in Portugal [4], estimating the energy consumption by the type of fuel used, by employing an input-output table (inter-industry relations table) [5], evaluating the environmental impact associated with air-conditioner use in four American cities [6], estimating the $\mathrm{CO}_{2}$ emissions associated with energy consumption in rural towns and cities in Japan [7] and using a regression model to estimate the relationship between temperature and electricity consumption [8]. The bottom-up approach is used to estimate the energy consumption for individual homes or groups. Examples of this approach include studies in which estimation models of energy consumption for each energy source and month were created [9-11], surveying the relationship between lifestyles (income, number of residents, etc.) and energy consumption, based on the usage time and the usage time zones of energy sources [12], evaluating the differences in electricity consumption relevant to a range of lifestyles [13], surveying energy consumption for each type of dwellings and/or energy source (fossil fuels and biomass) and use (heating and air-conditioning, kitchen use, etc.) [14, 15], assessing performance and/or contribution of district heating system for residential districts [16, 17] and assessing cost-effectiveness of Japanese energy efficiency standards program for home appliances [18], assessing sustainable energy community development methodologies in European countries. In addition, projections of energy consumption are essential in examining strategies for supplying energy $[7,10]$.

However, in many developed nations including Japan, there are concerns about the low birth rate and the ageing and decline of the population, as these factors lead to a change in the number of households. Such factors could change the future energy consumption and the structure of energy consumption in Japan. Hamza and Gilroy [19] have speculated that the further ageing of the society, coupled with a larger proportion of homes being owned by senior citizens with less personal disposable income, could cause fuel poverty. Fuel poverty, which is defined as households that are required to spend more than $10 \%$ of their income for all household energy use, including that needed to 
achieve the comfort levels (minimum temperature of $21^{\circ} \mathrm{C}$ in living rooms and $18{ }^{\circ} \mathrm{C}$ in all other rooms) set out by the World Health Organisation [19]. These factors are especially relevant to Japan, where the low birth rate and the ageing of the population are matters of significant concern and where fuel poverty could be a major future problem. Therefore, to address such concerns, the effects of a low birth rate, ageing, and the population decline on energy consumption and energy consumption structures have been examined.

In this study, Kobe, a Japanese city as a case study, was targeted to determine the rate of energy consumption for each household type, based on the usage time and the quantity of consumer durables that use energy. Using this rate, the projected future energy consumption for the entire residential sector of Kobe was calculated. The energy consumption of each building and household type had to be examined in detail for the projection. The top-down approach discussed above is characterised by lower accuracy compared with the bottom-up approach; however, the former facilitates large-scale evaluation. In contrast, studies based on the bottom-up approach evaluate individual homes and provide highly accurate evaluation results. However, as the number of households that could possibly be surveyed during this study was small, the bottom-up approach would have limited ability to classify the consumption patterns. Consequently, in this study, as the quantity and usage time of consumer durables in homes were focused on, the energy consumption by combining the top-down and bottom-up approaches was estimated. Accordingly, the quantity and usage time data for consumer durables were collected by using the bottom-up approach, with the energy consumption information prepared with these data being used as the basic unit rate. In this way, we combined the statistical data on the number of households used in the top-down approach to estimate the overall energy consumption of Kobe. This approach facilitates the estimation of the amounts of energy consumed and the associated energy consumption structures, if the number of households were to change because of the low birth rate and the population ageing.

\section{METHODS}

\section{Survey implementation}

Figure 1 shows the target area. The target area of this study was Kobe, Japan, with land area of $557.02 \mathrm{~km}^{2}$ and a population of approximately 1.54 million (2015), the sixth highest population among the cities designated by government ordinance in the country. The latitude and longitude of Kobe are $34^{\circ} 41^{\prime} 0 " \mathrm{~N}$ and $135^{\circ} 10^{\prime} 0^{\prime \prime} \mathrm{E}$. Average outside air temperature in 2015 is $17.3{ }^{\circ} \mathrm{C}$ (maximum temperature is $36.0{ }^{\circ} \mathrm{C}$ and minimum temperature is $-0.9^{\circ} \mathrm{C}$ ). Population aged 65 and above is $26.6 \%$, which is slightly higher than the value in Japan $(26.0 \%)$ [20, 21]. According to the National Institute of Population and Social Security Research (NIPSSR) [22], a decline in the population of Kobe is expected starting in 2015. In addition, the population aged 65 and above is expected to rise to $29.9 \%$ in 2020 and $32.7 \%$ in 2030 . Therefore, although Kobe is currently a city with a large population, its rate of ageing is progressing at a remarkably high level compared with that of other large cities.

To start the study, we conducted a survey in the form of a questionnaire to clarify the relationship in the residential sector between energy consumption and the household type. The questions were related to the usage time and the quantity of consumer durables that use energy in each household in Kobe. The respondents answered the questionnaire online. The main questions were:

- Household composition and residential status;

- Quantity of consumer durables and daily usage time;

- A history of home renovation. 
The respondents were 1,300 individuals of Kobe registered with a survey firm. The survey period was 16 to 24 November 2015.

Forty-three types of consumer durables were identified in the survey, including appliances used for cooking, hot water, household chores, and leisure, as well as electric cars, and others that use electricity, gas, or paraffin (lamp oil or kerosene) (Table 1). The energy consumption of seasonal consumer durables, such as air conditioners, can be expected to change significantly according to the season. Therefore, this survey made the respondents recall the usage time of the appliances for the whole year. The year was divided into four periods, namely, October to December 2014, January to March 2015, April to June 2015, and July to September 2015. The respondents were required to indicate the average usage times over each period (Figure 2). The survey period was limited to one year, as this survey assumed that the respondents would not be able to recall the typical usage time for longer than approximately one year. The accuracy of the questionnaire method employed in this study was not as high as that of methods that measure the electricity consumption of each home. However, since surveying each home would be time consuming, it would be difficult to obtain samples from a large number of homes. Although the questionnaire method is assumed less accurate, the advantage of this method is the large quantity of samples that could be gathered. Obtaining a large number of samples is specifically required for the calculation of the rates of energy consumption; therefore, the questionnaire survey method was decided to use for the present study.

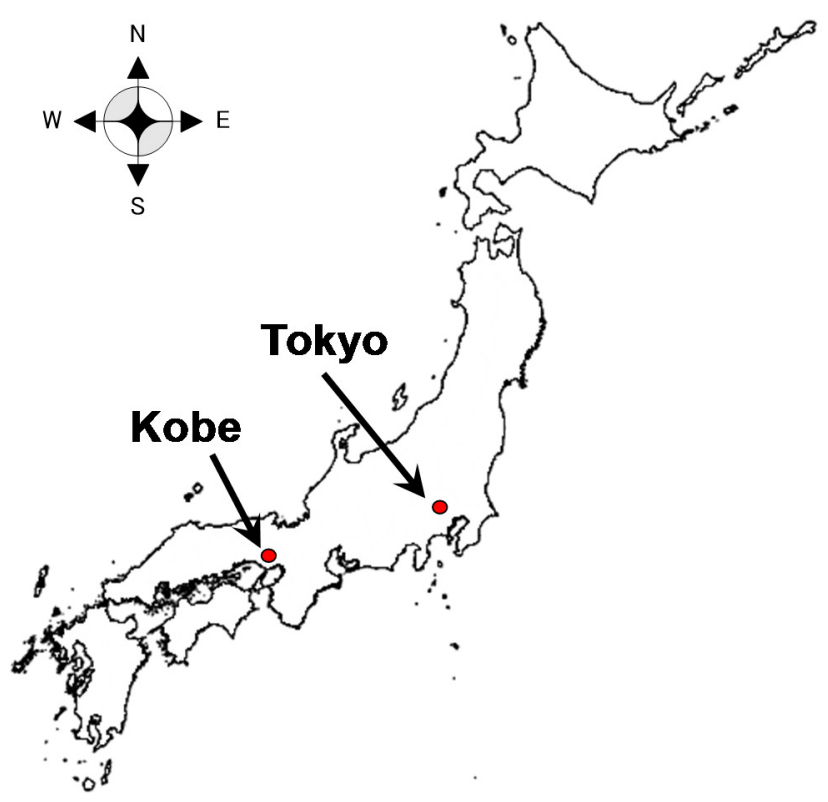

Figure 1. Location of Kobe

Table 1. Target consumer durables

\begin{tabular}{cc}
\hline Household equipment (13 types) & $\begin{array}{c}\text { Induction heat cooking heater, toilet bowl with warm water flush system for washing } \\
\text { user, floor heater (electric, electric hot water, and gas hot water), electric water } \\
\text { boiler, gas water boiler, oil water boiler, central heating and cooling, solar power } \\
\text { system, solar heating system, other energy producing devices, built-in stovetop }\end{array}$ \\
$\begin{array}{c}\text { Microwave oven, rice cooker, refrigerator (<300 L and } \geq 300 \text { L), clothes washer } \\
\text { (combination washer/dryer, drum type, automatic, twin tub, etc.), vacuum cleaner, } \\
\text { dishwasher, air conditioner (<21.9 } \mathrm{m}^{2} \text { and } \geq 21.9 \mathrm{~m}^{2} \text { ), heater [electric, city gas, } \\
\text { Liquid Petroleum Gas (LPG), oil burning, etc.], "kotatsu" (under-the-table heater), } \\
\text { air purifier, central air conditioner }\end{array}$ \\
\hline Household durables (18 types) \\
\hline Lights and bulbs (6 types) & $\begin{array}{c}\text { Fluorescent light, Light-Emitting Diode (LED) ceiling light, incandescent light bulb, } \\
\text { fluorescent light bulb, night-light bulb, LED light bulb }\end{array}$ \\
\hline Transportation (3 types) & Motorised bicycle, plug-in hybrid vehicle, electric vehicle \\
\hline Television, personal computer, video recorder \\
\hline
\end{tabular}




\section{Induction heat cooking heater}

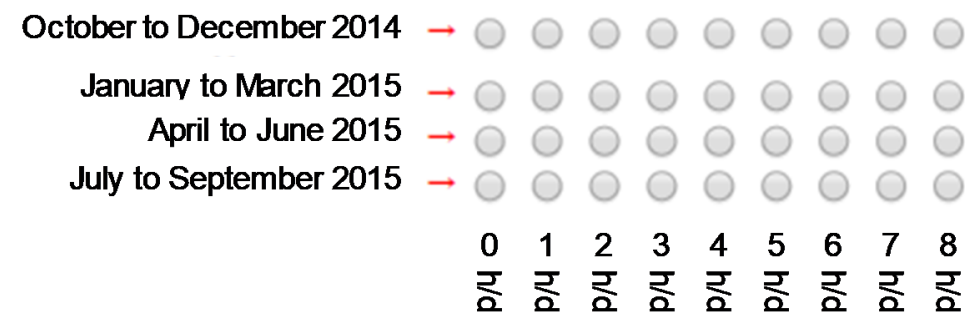

Refrigerator

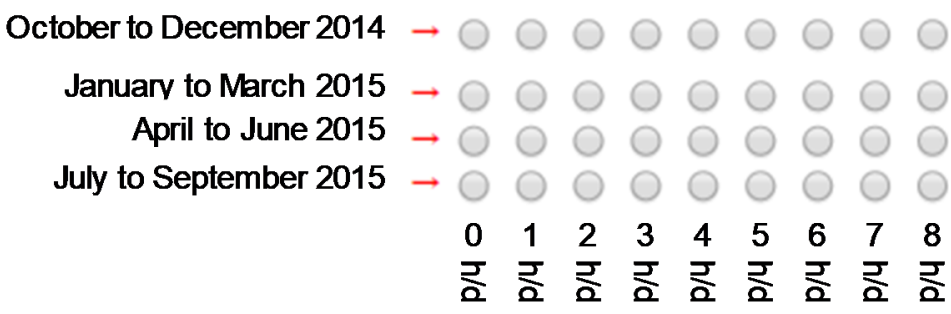

Television

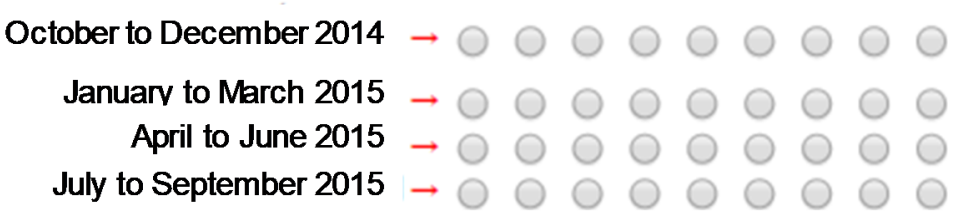

Figure 2. Screenshot of web-based questionnaire

\section{Annual energy consumption per household}

Subsequently, using the information obtained from the questionnaire, the annual energy consumption per household was calculated by multiplying the quantity and usage time of the consumer durables per household with the unit of energy consumption of the consumer durable. The energy consumption was calculated with the following equation:

$$
E=\sum_{x=1}\left(C_{x} \times P_{x} \times U_{x} \times d \times 3,600\right)
$$

The conversion factor from electricity to energy is $3,600 \mathrm{~J} / \mathrm{Wh}$. The annual usage days of consumer durables was set at 365 days.

The unit rate of energy consumption for consumer durables was calculated by extracting, organising, and statistically analysing the data. These data include the rated power consumption, rated output, and the annual energy consumption for each consumer durable product, which were gathered from websites.

For each sample obtained from the questionnaire, the energy consumption per household was calculated using eq. (1). Subsequently, these data was classified by household type, and the energy consumption by household type was calculated.

Using the annual rate of energy consumption per household, calculated with eq. (1), as the basic unit rate, the energy consumption of the residential sector in Kobe was calculated by multiplying this rate by the number of households in the city. The NIPSSR [22] offers projections on the number of households in Japan up to the year 2035, and this data was used in this study to estimate the future energy consumption of the residential sector. The rate of energy consumption for each household type was assumed that the rate would not change in the future. 


\section{RESULTS AND DISCUSSION}

\section{Questionnaire results}

Table 2 shows sample the demographics, which are our questionnaire results. Table 3 shows the data on the quantity, usage time, and rate of energy consumption for the main consumer durables.

Table 2. Demographics of questionnaire results $(\mathrm{N}=1,300)$

\begin{tabular}{|c|c|c|c|c|c|c|c|}
\hline \multirow{10}{*}{$\begin{array}{c}\text { Respondent age } \\
\text { (5-year } \\
\text { increments) }\end{array}$} & $20-24$ & 65 & $(5 \%)$ & \multirow{11}{*}{$\begin{array}{l}\text { Age of head of } \\
\text { household } \\
\text { (5-year } \\
\text { increments) }\end{array}$} & $20-24$ & 26 & $(2 \%)$ \\
\hline & $25-29$ & 104 & $(8 \%)$ & & $25-29$ & 65 & $(5 \%)$ \\
\hline & $30-34$ & 117 & $(9 \%)$ & & $30-34$ & 65 & $(5 \%)$ \\
\hline & $35-39$ & 143 & $(11 \%)$ & & $35-39$ & 117 & $(9 \%)$ \\
\hline & $40-44$ & 130 & $(10 \%)$ & & $40-44$ & 130 & $(10 \%)$ \\
\hline & $45-49$ & 143 & $(11 \%)$ & & $45-49$ & 130 & $(10 \%)$ \\
\hline & $50-54$ & 130 & $(10 \%)$ & & $50-54$ & 143 & $(11 \%)$ \\
\hline & $55-59$ & 117 & $(9 \%)$ & & $55-59$ & 130 & $(10 \%)$ \\
\hline & $60-64$ & 182 & $(14 \%)$ & & $60-64$ & 208 & $(16 \%)$ \\
\hline & $65-69$ & 169 & $(13 \%)$ & & $65-69$ & 208 & $(16 \%)$ \\
\hline \multirow{2}{*}{ Sex } & Male & 637 & $(49 \%)$ & & $70+$ & 78 & $(6 \%)$ \\
\hline & Female & 663 & $(51 \%)$ & \multirow[b]{2}{*}{ Children } & Yes & 520 & $(40 \%)$ \\
\hline \multirow{5}{*}{$\begin{array}{l}\text { Number of } \\
\text { individuals per } \\
\text { household }\end{array}$} & $\begin{array}{c}1 \text {-person } \\
\text { household }\end{array}$ & 260 & $(20 \%)$ & & No & 780 & $(60 \%)$ \\
\hline & $\begin{array}{c}\text { 2-person } \\
\text { households }\end{array}$ & 429 & $(33 \%)$ & \multirow[b]{2}{*}{ Type of housing } & $\begin{array}{l}\text { Detached } \\
\text { home }\end{array}$ & 533 & $(41 \%)$ \\
\hline & $\begin{array}{c}\text { 3-person } \\
\text { households }\end{array}$ & 299 & $(23 \%)$ & & $\begin{array}{c}\text { Housing } \\
\text { complex, } \\
\text { etc. }\end{array}$ & 767 & $(59 \%)$ \\
\hline & $\begin{array}{c}\text { 4-person } \\
\text { households }\end{array}$ & 234 & $(18 \%)$ & \multirow[b]{2}{*}{ Homeownership } & Own & 910 & $(70 \%)$ \\
\hline & $\begin{array}{l}5 \text { or more } \\
\text { person } \\
\text { households }\end{array}$ & 78 & $(6 \%)$ & & Renting & 390 & $(30 \%)$ \\
\hline
\end{tabular}

Table 3. Quantity, usage time, and unit of energy consumption of main items

\begin{tabular}{cccc}
\hline Items & $\begin{array}{c}\text { Quantity (mean) } \\
\text { [unit/household] }\end{array}$ & $\begin{array}{c}\text { Usage time } \\
{[\mathrm{h} / \mathrm{unit}]}\end{array}$ & $\begin{array}{c}\text { Unit of energy } \\
\text { consumption [W/unit] }\end{array}$ \\
\hline Built-in stovetop & 1.09 & 1.16 & 2,970 \\
Induction heat cooking heater & 0.36 & 0.66 & 5,800 \\
Washer (automatic, twin tub, etc.) & 0.65 & 1.42 & 88 \\
Television & 1.88 & 5.64 & 90 \\
Personal computer & 1.78 & 4.5 & 16.84 \\
Air conditioner $\left(<21.9 \mathrm{~m}^{2}\right)$ & 1.82 & 3.05 & 590 \\
\hline
\end{tabular}

\section{Estimation of energy consumption}

Table 4 shows the annual energy consumption per household calculated by using the results of Table 2, whereas Table 5 shows the energy consumption by the age of the head of the household. In addition, Figure 3 shows an estimation of the mean energy consumption per household by the number of individuals per household, and the age of the head of household. Since the standard deviation of the mean value was high for each item, we used the energy consumption calculated from the median. 
Table 4. Annual energy consumption per household by number of individuals per household (median)

\begin{tabular}{|c|c|c|c|}
\hline $\begin{array}{c}\text { Total household } \\
{[\mathrm{MJ} /(\text { household } \times \mathrm{yr})]}\end{array}$ & 39,640 & $\begin{array}{l}\text { 3-person households } \\
{[\mathrm{MJ} /(\text { household } \times \mathrm{yr})]}\end{array}$ & 41,650 \\
\hline $\begin{array}{l}\text { 1-person household } \\
{[\mathrm{MJ} /(\text { household } \times \mathrm{yr})]}\end{array}$ & 23,980 & $\begin{array}{l}\text { 4-person households } \\
{[\mathrm{MJ} /(\text { household } \times y r)]}\end{array}$ & 47,490 \\
\hline $\begin{array}{l}\text { 2-person households } \\
{[\mathrm{MJ} /(\text { household } \times \mathrm{yr})]}\end{array}$ & 39,680 & $\begin{array}{c}5 \text { and more person households } \\
{[\mathrm{MJ} /(\text { household } \times \mathrm{yr})]}\end{array}$ & 53,910 \\
\hline
\end{tabular}

Table 5. Energy consumption by the age of the head of a household (median)

\begin{tabular}{|c|c|c|c|}
\hline 20-24 [MJ/(household×yr)] & 21,720 & 50-54 [MJ/(household×yr)] & 40,510 \\
\hline 25-29 [MJ/(household $\times y r)]$ & 27,760 & 55-59 [MJ/(household $\times y r)]$ & 39,170 \\
\hline 30-34 [MJ/(household $\times y r)]$ & 32,890 & 60-64 [MJ/(household $\times y r)]$ & 42,080 \\
\hline 35-39 [MJ/(household $\times y r)]$ & 35,060 & 65-69 [MJ/(household×yr)] & 45,320 \\
\hline 40-44 [MJ/(household×yr)] & 39,410 & $70+[\mathrm{MJ} /($ household $\times \mathrm{yr})]$ & 54,240 \\
\hline 45-49 [MJ/(household×yr)] & 34,520 & & \\
\hline
\end{tabular}

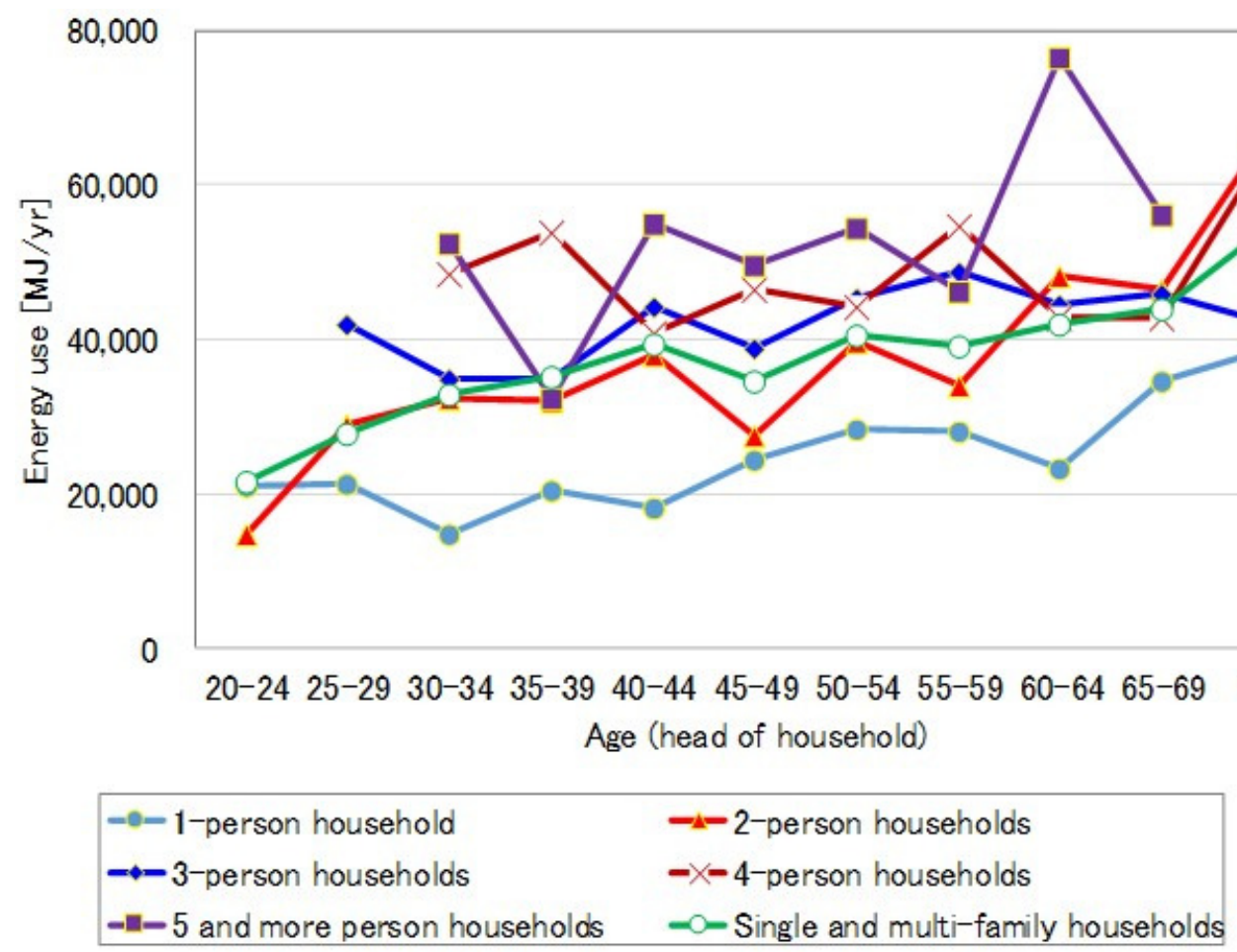

Figure 3. Energy consumption per household by number of individuals per household and age of the head of household at Kobe

The results show that as the number of people in the household increased, the energy consumption also increased because of the increase in the number and usage time of the consumer durables. In addition, as the age of the head of household increased, energy consumption also increased.

The top six consumer durables with high-energy consumption per household are water heaters $(34.8 \%)$, air conditioners $(11.7 \%)$, built-in stovetops $(8.7 \%)$, induction heat cooking heater $(5.9 \%)$, lighting $(4.8 \%)$, and toilet bowl with warm water flush system for washing user $(3.7 \%)$. These six items accounted for approximately $70 \%$ of the overall 
energy consumption in the households. Energy consumption of lighting contains various lights and bulbs including LED ceiling lights and LED light bulbs. Previous study of Tabata and Moon [23] reveals that estimated LED light bulbs penetration is approximately 5\% at Nagoya, Japan in 2010. Energy consumption of lighting might gradually decrease by further growth of LED light bulbs.

Figure 4 shows our estimation of the energy consumption by energy use. With an increase in the number of individuals per household, the consumption increased for all the items. The ratio of energy consumption for heating increased with the increased number of individuals per household. Furthermore, energy for the kitchen use and appliances and lighting tended to decrease as the number of individuals per household increased.

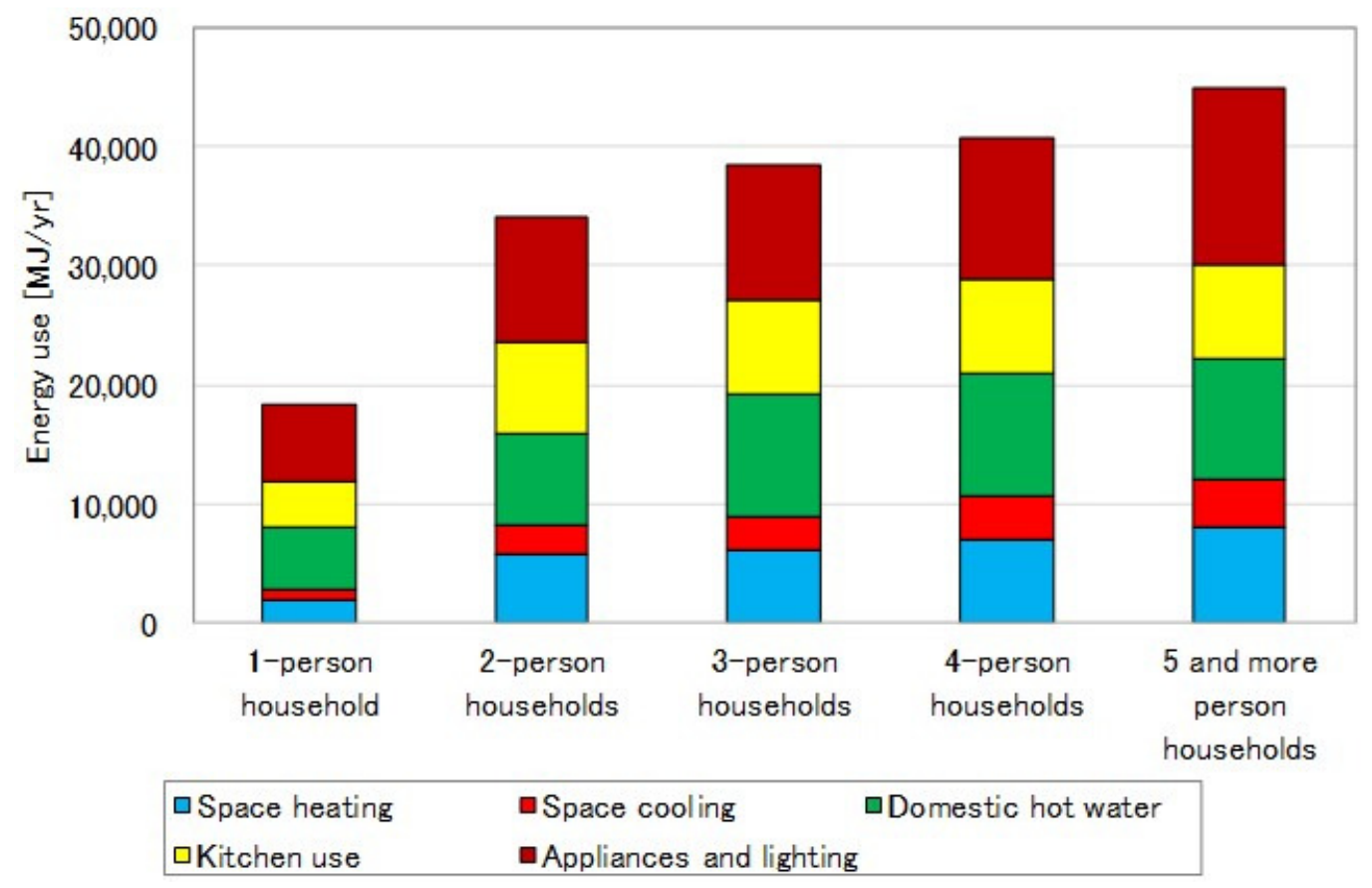

Figure 4. Energy consumption per household by number of individuals per household and amount of energy use at Kobe

By using above mentioned results, energy consumption of household sector in Kobe in 2010 was estimated at approximately 25,559 TJ. Actual energy consumption of this city was 23,873 TJ [24] and the difference between estimated value and actual one was approximately $3 \%$. This result indicates that an appropriate estimation was gained. In the next section, above results was utilized to estimate future energy consumption.

By multiplying the rate of energy consumption for the number of individuals per household by the number of households, the energy consumption of the entire Kobe could be estimated. This estimation is applicable to the years 2010-2035 and the NIPSSR [22] estimation was used in the estimation of the future population and the number of future households. Based on the NIPSSR data, it was assumed that the number of households would change in the future and the percentage of 1-person household would increase.

Future projection of number of the households are shown in Figure 5 and the estimated changes in energy consumption are shown in Figure 6. The results show that as the number of households was expected to start declining from 2020, the amount of energy consumed would also start to decline from 2020. Although the number of one-person households would increase, the total number of households would decrease; therefore, energy consumption in 2035 would decline by approximately $6.0 \%$ from 2010 . 
The rate of energy consumption by the age of the head of the household was subsequently used to estimate future energy use. The results show that as the number of households decreased, the energy consumption in 2035 would be $4.4 \%$ lower than that of 2010 . $30.3 \%$ of the total energy consumption also would be households with the head of the household being 70 years old or older.

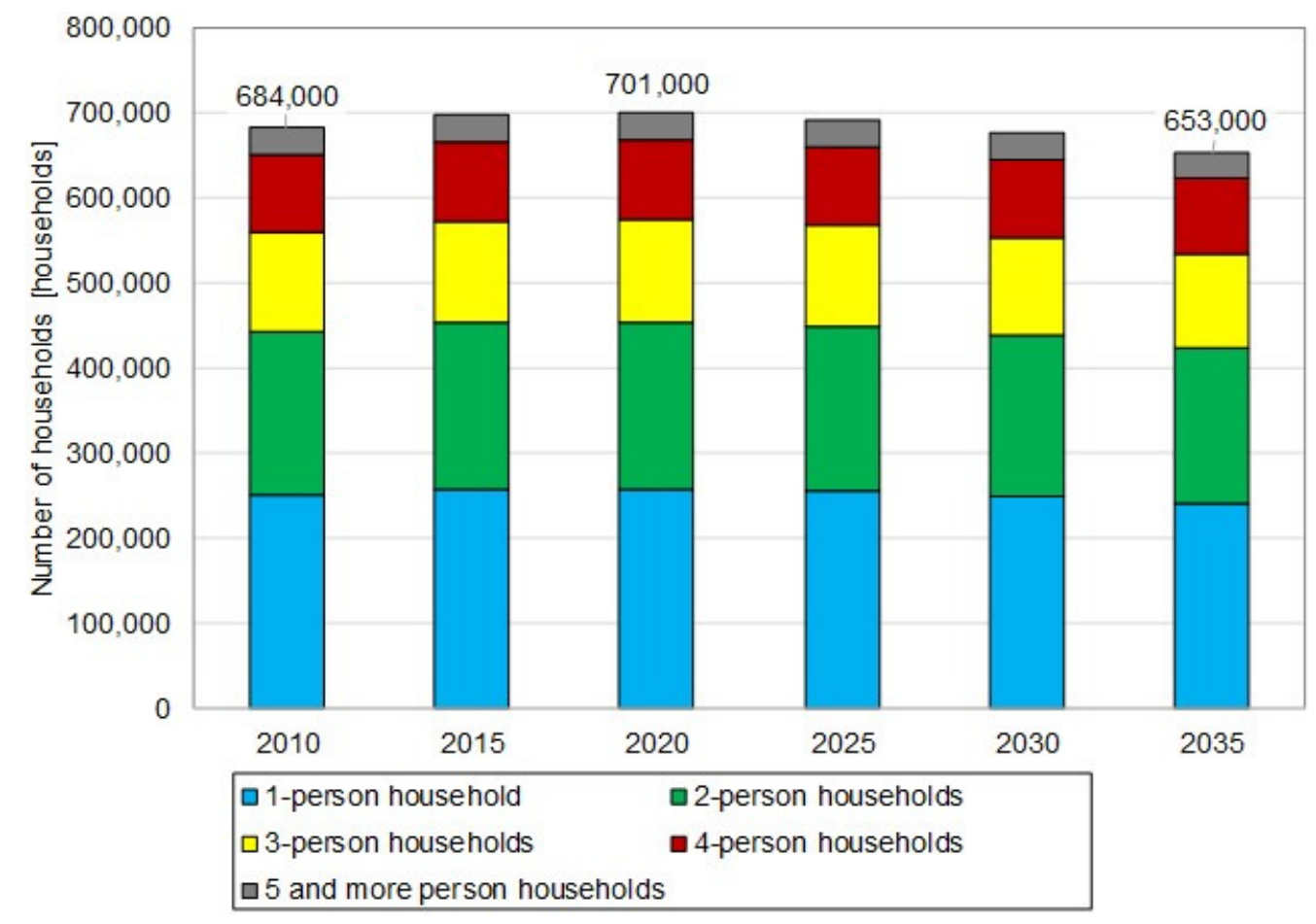

Figure 5. Future projection of number of the households at Kobe [22]

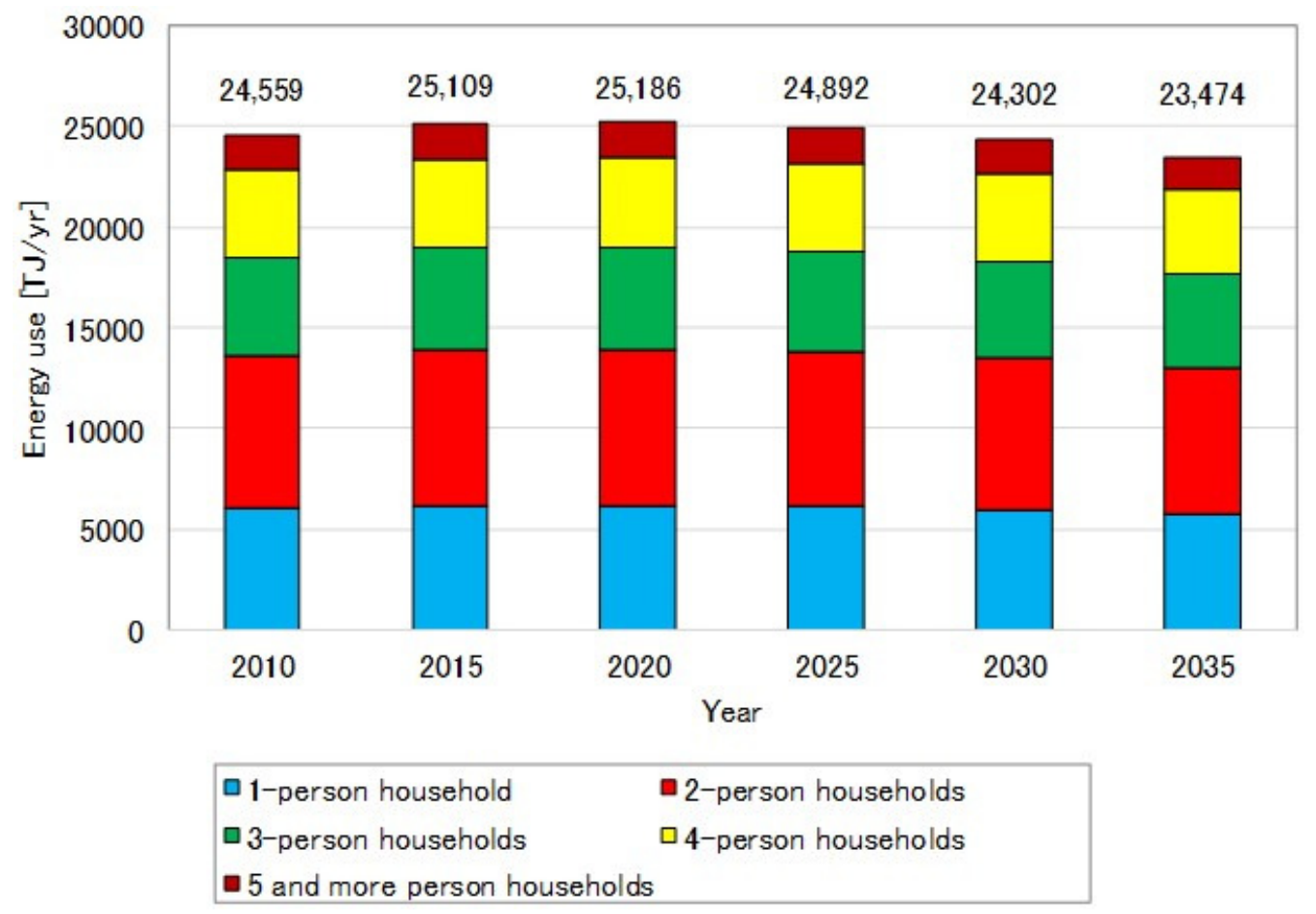

Figure 6. Changes in energy consumption in household sector at Kobe

In accordance with the information obtained from the questionnaire, we assumed that households with zero gas consumption would be "all-electric" households. The amount 
of annual energy consumption per household was 38,070 MJ for all-electric households and 39,705 MJ for all "non-all-electric" households, indicating that the energy consumption in the all-electric households was $4.1 \%$ lower. Consequently, the energy consumption by the city in general is expected to decline with more widespread use of all-electric systems. For example, induction heat cooking heaters, the market size in 2012 was approximately 740,000 units (amounting to approximately 4.78 million USD at a conversion rate of JPY $1=$ USD 0.0087, as of December 5, 2016) [25]. In comparison, the market size for built-in stovetops in 2011 is expected to be approximately 1,300,000 units [26]. Although the market size of induction heat cooking heaters would be smaller than that of built-in stovetops, this type of cooker would be chosen often during renovation, especially by households of seniors, as they do not use an open flame and are seen as safer. Based on this finding, we analysed the effect of full electrification of residential houses on energy consumption structures in households that were not currently fully electrified.

Currently, all-electric households are assumed to be approximately $10 \%$ of the overall number of households, based on the questionnaire results. We estimated the changes in energy consumption by assuming that $10 \%$ to $90 \%$ of the current non-all-electric households would be renovated to use all-electric systems. The timing of renovations was assumed to be when the head of the household reached 60-65 years (using five-year increments), between 2020 and 2035. This indication of the time is based on the questionnaire results.

Figure 7 shows the results for the assumed renovations. In the event that the rate of renovation to all-electric systems reached $90 \%$, compared with $0 \%$, the energy consumption would decline by approximately $1 \%$, although this figure is quite small. In contrast with decline of oil fuel consumption, electricity consumption would increase. Therefore, a renovation-based switch to all-electric systems could change the energy consumption structure of the households significantly. For example, Kobe promotes renewable energy supply for substitution of gas demand. But aged persons tend to prefer the all-electric systems for their safety. If renovation of all-electric systems were promoted, Kobe might have to rethink their renewable energy strategy in the future.

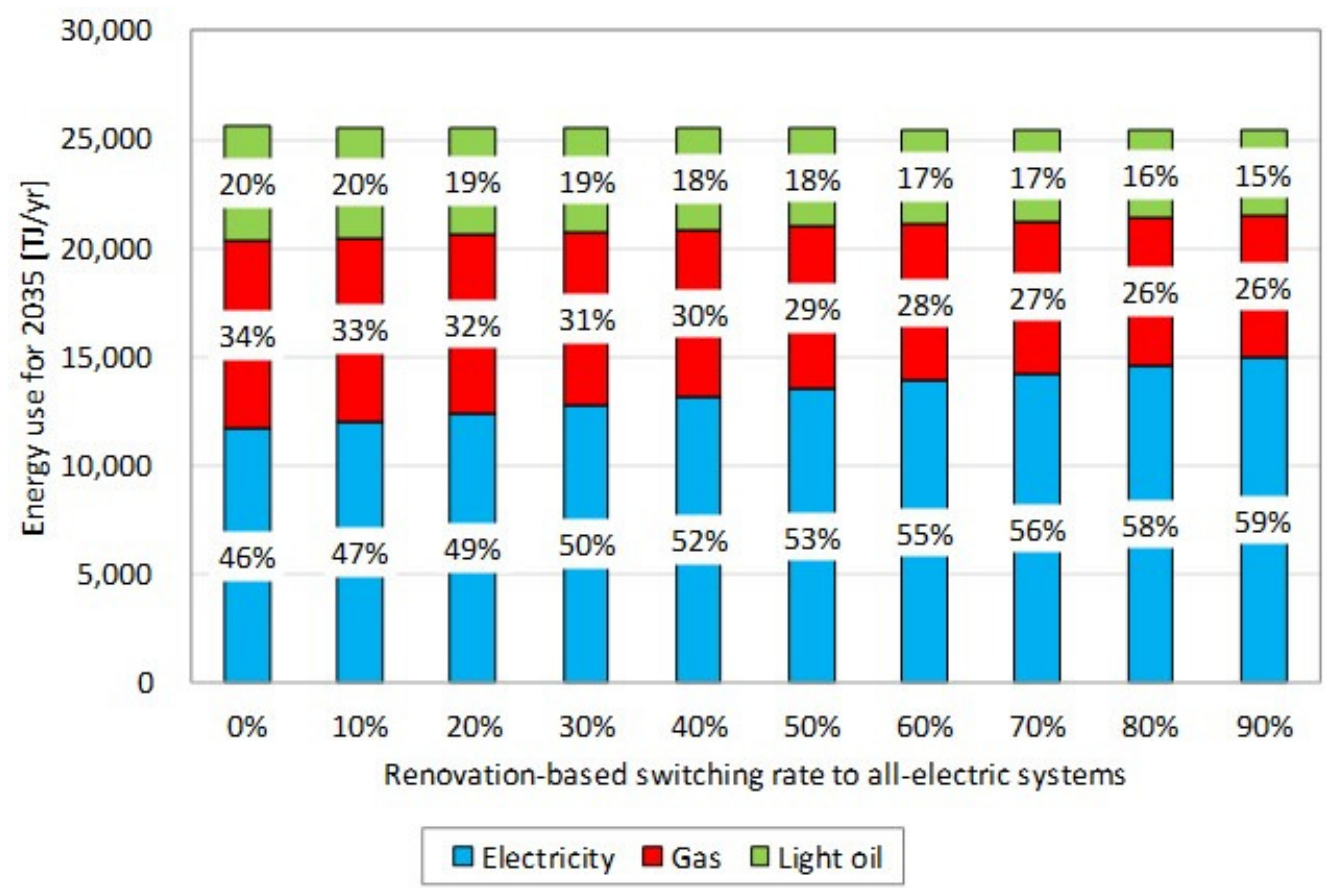

Figure 7. Relationship between renovation rate to all-electric systems and related energy consumption (estimate for 2035) 


\section{CONCLUSIONS}

In this study, based on the quantity and usage time of consumer durables, the rate of energy consumption for each household type and presented projections of the future energy consumption by the residential sector in Kobe was calculated. The following conclusions are the results of this scenario analysis:

- As the number of people in the household increased and the age of the head of household increased, the energy consumption increased;

- Energy use in 2035 will decrease by $4.4 \%$ according to decline of population and number of household compared with in 2010;

- Full electrification of residential houses would change energy consumption structures rather than overall energy consumption.

One of our main findings from the survey revealed that factor for increase of energy consumption is not only increase of number of households but also increase of aged person. Local municipalities should consider the transition of ageing population if they were discussing the future projection of energy consumption in the city. Another main finding requires local municipalities to preliminary investigate a possibility of change of household energy consumption and/or household energy consumption structure by considering various factors such as increase of aged person and renovation of residential houses to all-electric systems. These factors might affect feasibility of local municipalities' renewable energy strategy.

Some limitation of this study remains. For example, this study is only over one target area, and estimation at another area is required. Energy consumption varies from city scale such as metropolitan area and rural one. We also roughly asked quantity and daily usage time of consumer durables from inhabitants. We need to quantify more precise data. However, the present method and the rate of energy consumption provided by this study could be useful for the detailed estimation of energy consumption and to propose finely adjusted energy saving measures to local municipalities.

\section{ACKNOWLEDGEMENT}

This research was supported by the Environmental Research and Technology Development Fund [3K143015 and 3K143016] of the Ministry of Environment, Japan.

\section{NOMENCLATURE}

C

$d$

E

$P$

$U$

$x$ energy consumption of consumer durables

annual usage days of consumer durables

energy consumption

quantity of consumer durables

daily usage time of consumer durables

type of consumer durable

\author{
[W/unit] \\ [d/yr] \\ [J/(household $\times y r)]$ \\ [unit/household] \\ [h/d] \\ $[-]$
}

\section{REFERENCES}

1. Japan Agency for Natural Resources and Energy, Energy White Paper 2015 (in Japanese), Tokyo, Japan, http://www.enecho.meti.go.jp/about/whitepaper, [Accessed: 06-December-2016]

2. Jyukankyo Research Institute Inc., 2014 Household Energy Handbook, Jyukankyo Research Institute Inc., Tokyo, Japan, 2014.

3. Swan, L. G. and Ugursal, V. I., Modeling of End-use Energy Consumption in the Residential Sector: A Review of Modeling Techniques, Renew. Sust. Energ. Rev., Vol. 13, No. 8, pp 1819-1835, 2009, https://doi.org/10.1016/j.rser.2008.09.033 
4. Goncalves, A. and Domingos, T., Scaling Laws and Electricity Consumption in Cities: A Sectoral View, Int. J. Sust. Energ. Plann. Manag., Vol. 2, pp 19-32, 2014, http://dx.doi.org/10.5278/ijsepm.2014.2.3

5. Cellura, M., Longo, S. and Mistretta, M., The Energy and Environmental Impacts of Italian Households Consumptions: An Input-output Approach, Renew. Sust. Energ. Rev., Vol. 15, No. 8, pp 3897-3908, 2011, https://doi.org/10.1016/j.rser.2011.07.025

6. Shah, V. P., Debella, D. C. and Ries, R. J., Life Cycle assessment of Residential Heating and Cooling Systems in Four Regions in the United States, Energ. Buildings, Vol. 40, No. 4, pp 503-513, 2008, https://doi.org/10.1016/j.enbuild.2007.04.004

7. Ashima, S. and Nakata, T., Energy-efficiency Strategy for $\mathrm{CO}_{2}$ Emissions in a Residential Sector in Japan, Appl. Energ., Vol. 85, No. 2-3, pp 101-114, 2008, https://doi.org/10.1016/j.apenergy.2007.06.011

8. Fumo, N. and Biswas, M. A. R., Regression Analysis for Prediction of Residential Energy Consumption, Renew. Sust. Energ. Rev., Vol. 47, pp 332-343, 2015, https://doi.org/10.1016/j.rser.2015.03.035

9. Bidaj, F., Alushaj, R., Prifti, L. and Chittum, A., Evaluation of the Heating Share of Household Electricity Consumption using Statistical Analysis: A Case Study of Tirana, Albania, Int. J. Sust. Energ. Plann. Manag., Vol. 5, pp 3-14, 2015, http://dx.doi.org/10.5278/ijsepm.2015.5.2

10.Gendebien, S., Georges, E., Bertagnolio, S. and Lemort, V., Methodology to Characterize a Residential Building Stock using a Bottom-up Approach: A Case Study applied to Belgium, Int. J. Sust. Energ. Plann. Manag., Vol. 4, pp 71-88, 2014, http://dx.doi.org/10.5278/ijsepm.2014.4.7

11.Mohammed, M. A. and Budaiwi, I. M., Strategies for reducing Energy Consumption in a Student Cafeteria in a Hot-Humid Climate: A Case Study, J. Sustain. Dev. Energy Water Environ. Syst., Vol. 1, No. 1, pp 14-26, 2013, https://doi.org/10.13044/j.sdewes.2013.01.0002

12.Silva, A. S., Luiz, F., Mansur, A. C., Vieira, A. S., Schaefer, A. and Ghisi, E., Knowing Electricity End-uses to Successfully Promote Energy Efficiency in Buildings: A Case Study in Low-income Houses in Southern Brazil, Int. J. Sust. Energ. Plann. Manag., Vol. 2, pp 7-18, 2014, http://dx.doi.org/10.5278/ijsepm.2014.2.2

13.Ozawa, A., Furusato, R. and Yoshida, Y., Determining the Relationship between a Household's Lifestyle and its Electricity Consumption in Japan by analyzing measured Electric Loadprofiles, Energ. Buildings, Vol. 119, pp 200-210, 2016, https://doi.org/10.1016/j.enbuild.2016.03.047

14.Li, X., Wang, Y., Zhao, L., Duan, N. and Wu, X., Analysis of Rural Household Energy Consumption and Renewable Energy Systems in Zhangziying Town of Beijing, Ecol. Model., Vol. 318, pp 184-193, 2015, https://doi.org/10.1016/j.ecolmodel.2015.05.011

15.Alrashed, F. and Asif, M., Trends in Residential Energy Consumption in Saudi Arabia with Particular Reference to the Eastern Europe, J. Sustain. Dev. Energy Water Environ. Syst., Vol. 2, No. 4, pp 376-387, 2014, https://doi.org/10.13044/j.sdewes.2014.02.0030

16.Ahvenniemi, H. and Klobut, K., Future Services for District Heating Solutions in Residential Districts, J. Sustain. Dev. Energy Water Environ. Syst., Vol. 2, No. 2, pp 127-138, 2014, https://doi.org/10.13044/j.sdewes.2014.02.0012

17.Mikulandrić, R., Krajačić, G., Duić, N., Khavin, G., Lund, H., Vad Mathiesen, B. and Østergaard, P., Performance Analysis of a Hybrid District Heating System: A Case Study of a Small Town in Croatia, J. Sustain. Dev. Energy Water Environ. Syst., Vol. 3, No. 3, pp 282-302, 2015, https://doi.org/10.13044/j.sdewes.2015.03.0022

18.Arakawa, J. and Akimoto K., Assessment of the Japanese Energy Efficiency Standards Program, J. Sustain. Dev. Energy Water Environ. Syst., Vol. 3, No. 1, pp 66-78, 2015, https://doi.org/10.13044/j.sdewes.2015.03.0005 
19.Hamza, N. and Gilroy, R., The Challenge to UK Energy Policy: An Ageing Population Perspective on Energy Saving Measures and Consumption, Energ. Policy, Vol. 39, No. 2, pp 782-789, 2011, https://doi.org/10.1016/j.enpol.2010.10.052

20.Hyogo Prefecture, Relevant Documents for Aged Person, Health and Welfare (in Japanese), 2016, https://web.pref.hyogo.lg.jp/hw07/hw07_000000012.html, [Accessed: 06-December-2016]

21.Japan Cabinet Office, 2015 Annual Report on the Aging Society (in Japanese), 2015, http://www8.cao.go.jp/kourei/whitepaper/index-w.html, [Accessed: 06-December-2016]

22.National Institute of Population and Social Security Research, Household Projections by Prefecture in Japan: 2010-2035, 2014, http://www.ipss.go.jp/pp-ajsetai/e/hhprjpref2014/t-page_e.asp,

[Accessed: 06-December-2016]

23.Tabata, T. and Moon, D., Environmental and Economic Valuations of Conversion Measure of Light Bulbs using Household Data (in Japanese), Environ. Sci., Vol. 25, pp 367-377, 2012.

24.City of Kobe, 2010 Greenhouse Gases Emission in Kobe (in Japanese), http://www.city.kobe.lg.jp/information/press/2012/08/20120828194601.html, [Accessed: 06-December-2016]

25.The Remodelling Business Journal, Market Data (in Japanese), No. 1106, p 4, 2014 , http://www.reform-online.jp/story/3881.php, [Accessed: 06-December-2016]

26. The Remodelling Business Journal, Market Data (in Japanese), No. 1102, p 4, 2013, http://www.reform-online.jp/story/3881.php, [Accessed: 06-December-2016] 